\title{
IMPACT OF ORGANIZATIONAL CULTURE ON EMPLOYEES JOB PERFORMANCE IN SOFTWARE HOUSES
}

\author{
Fajar Lateef ${ }^{1}$
}

\begin{abstract}
This paper intends to examine the general impact of organizational culture directly or indirectly on employees' job performance. To find the impact of organizational culture on employee performance within software houses. This is a survey-based research study. Primary and secondary data were used in this study. Primary data were collected through questionnaire and formal and informal interview. Customer service, employee participation, reward system, innovation and risk-taking and communication system are reflected variables for this study. Sample size is $(n=110)$; therefore, descriptive statistics, correlation analysis and regression analysis have been used. The overall results support that culture of organizations has a significant positive impact on employees' job performance at software houses. Employees' contribution is the most important element for achieving organizational goals. This study achieves an acknowledged necessity of learning the impact of culture on the job performance of employees of the software industry.

Keywords: Organizational Culture, Employee Performance, Risk-Taking and Innovation, Employees' Participation.
\end{abstract}

\section{INTRODUCTION}

Organizational culture is a set of shared values, beliefs and experiences between each member in the organization. Culture consists of certain categories such as shared values and norms of behavior (Robbins, 1996). In the past decades, organizational culture is an important subject in management and business research due to its effect on the outcomes of individual and organization such as job satisfaction and performance (Robbins, 1996).

Moreover, job performance is the achievement of a designed task with a time set and done by a person which later will measure by using performance management (Shahzad, 2012).

\footnotetext{
${ }^{1}$ Institute of Business Management, Karachi, Pakistan
} 
According to (Sofijanova, \& Zabijakin-Chatleska, 2013), the researchers indicated that the employee empowerment and employee involvement are important components to contribute towards success in the organization. There are researchers indicate that the way to measure performance affects the perception on the performance measurement system (Pillania, Victoria Garibaldi Hilal, Wetzel, \& Ferreira, 2009). A strategic performance measurement system (SPMS) is a new path to measure and evaluate the performance of employees. Hence, this study is conducted to investigate the relationship between organizational culture and job performance. Following are the key areas covered in this study with their operational classifications.

\section{Employee Participation}

Employee participation is the process whereby employees are involved in decision making processes, rather than simply acting on orders. Employee participation is a process of empowerment in the workplace. Empowerment involves decentralizing power within the organization to Employee participation is in part a response to the quality individual decision makers further down the line (Uma, 2015)

\section{Innovation and Risk Taking}

Creativity means to produce something from nothing, whereas innovation makes sense of that something into goods and services. Innovation is considered an environment or a culture that has almost a divine power which exists in the organization and which caused to drive value creation. (Robbins, Stepehen \& Coulter, 1996) have identified three sets of variables that are responsible for stimulating innovation: organization's structure, organization's culture and HR practices.

\section{Rewards system}

Theory of reinforcement described that the rewards should be exploited to strengthen the appropriate behaviors only and reinforces for undesirable performance should be removed. Luthans (Luthans \& Youssef, 2007) states that an organization should have the most up-to-date technology, well-designed strategic plans, comprehensive job descriptions and inclusive training courses, but unfortunately, people are being rewarded based on performance-related behaviors of the employees, and there is a limited impact of technology, plans or rules. It is demonstrated that for reinforcing an organization's culture, the organization's reward system is considered a powerful tool. 


\section{Openness to Communication}

Chester Barnard states that functions of the executives were, firstly, to develop the thoughts of communication considered as a key shaping strength in an organization (Luthans \& Youssef, 2007). Good communication helps the employees to keep running internal processes consistently and also helps to create superior association with the people, both within and outside the organization. According to Luthans (Luthans \& Youssef, 2007 ) effective communication plays a very important role in industrial disagreements, miscommunication, gossips and organizational divergences.

\section{Customer Service Orientation}

Leveny Joel and Michelle (2000) state that employees observe the organization's procedures as believing them well and giving wisdom of society at workplace and got the customers' report regarding the quality of services. High service quality could result when the organizational culture communicates advanced customer service at the top.

\section{STATEMENT OF THE PROBLEM}

This study explores the employees' perspectives based on the employee participation, opens to communication, risk taking and innovation, customer service innovation and reward system, which majorly constitutes an organizational culture that prevails. Organizational can generate an important role towards employees' performance. It leads as a result of the motivational factor of employees in their performance by linking the interest of employees to the organization. If the culture prevailing in an organization changes, there would be a change in work motivation and level of satisfaction which leads to employees' performance.

\section{RESEARCH QUESTIONS}

Q1. Is there any relationship between organizational culture and job performance in software industry?

Q2. Does employee participation have significant relationship with job performance?

Q3. Does openness to communication have significant relationship with job performance?

Q4. Does risk taking and innovation have significant relationship with job performance?

Q5. Does customer service orientation have significant relationship with job performance?

Q6. Does reward system have significant relationship with job performance? 


\section{OBJECTIVE OF THE STUDY}

The main objective of this study to is to determine the relationship between organizational culture and employees' job performance in a software house.

\section{SIGNIFICANCE OF THE STUDY}

The findings of this study will benefit the organizations in software industry in order to define the culture and subculture prevailing in an organization which can directly or indirectly impact the each of employee's performance and the performance of an organization will be impacted directly or indirectly.

\section{LIMITATIONS OF THE STUDY}

There are few limitations in this study. Firstly, the research only conducted in a software industry in Pakistan, as there are so many small- and large-scale software firms throughout the world. Secondly, few hours are too limited for data collection and it is unable to estimate the relationship between organizational culture and job performance. The method used for data collection is questionnaire by using Likert's scale.

\section{SCOPE OF THE STUDY}

The scope of this study is based only on the software houses within the Pakistan only which also limits the validity of the results. Moreover, there are so many other aspects which affects the job performance directly or indirectly but in regard of this study we are only using organizational culture as an independent variable and employee performance as a dependent variable.

\section{Assumptions}

Assumptions we have made while making the theoretical framework is that the Employee Participation, Openness to Communication, Risk taking and Innovation, Customer Service Innovation, Reward system are the major constituents that defines the culture of an organization. Additionally, there are a few more factors that would influence employees' job satisfaction and we are assuming those factors as constants. 


\section{LITERATURE REVIEW}

A company, large or small, is considered as a software house whose primary objective is to produce software. This requires highly technical skills and high level of understanding of software development. Software are developed and distributed throughout the world. Worldfamous software developers are Microsoft, Oracle Corporation, HP, Apple, etc. However, in almost every country, there are many other private software houses whose aim is to get a contract from organizations to develop software based on the required specifications. These organizations have their own culture, which could affect the performance of the employees in the organization.

The organizational culture proposed to the employees the way things should be done. Most of the time, people exercise word culture to express the pattern of individual behavior. Before 1980 s, in the study of organizational behavior, culture was considered as the most important factor. Businesses show interest in cultural dimensions that was the most extreme effect rather than the other fragments of organizational behavior. Peter and Waterman (Peters \& Waterman, 1982) assumed that culture is the key to the success of an organization. Many business journals and business articles, published periodically, claimed that culture was fundamental to organizational success, and it was recommended for the managers to deal with their work by following their organizational culture, which helped in the growth of the organization (Griffin, R; Moorhead, 2014). Researchers have linked culture in the organization with many different organizational behaviors. They have also recognized the correlation between culture of organization and employee job performance (Schein, 1992), decision making (Gamble \& Gibson, 1999) and productivity (Kopelman, Brief, \& Guzzo, 1990). (Luthans \& Youssef, 2007) Stated that organizational culture has always been present within the organization, but most of the time, businesses paid less thoughtfulness to it. The culture of an organization permeates every important component of the organization.

Understanding the association between employees' job performance and culture of the organization is an imperative research subject because findings of different studies have proved that an individual's work performance is crucial for the success of an organization, particularly in the software industry. Software developers and engineers are a part of the highly rising group of the global economy. Hence, they need an open environment where they can easily share their ideas, participate in decision making and provide help to each other. This environment can be developed by the culture of their organizations. Strong culture will make it easy to 
communicate openly and to participate efficiently and effectively in the decision making to explore their ideas and skills.

The study mentions that an organization can get the competitive advantage if the management creates and maintains a culture with high level of involvement of employees. Behavior and performance have not been discussed yet in the software industry in the literature of organizational behavior.

\section{Employee Participation}

Schein (Schein, 1992) considered participation of employees as a key element for setting organizational goals. As per goal-setting theory, participation of employees can increase goal acceptance. According to Zairi (1999) a key attribute is participation, which is positively related to overall effectiveness of the organization. He also stated that participation involves delegating tasks as per the individual's responsibilities.

\section{Innovation and Risk taking}

Creativity means to produce something from nothing, whereas innovation makes sense of that something into goods and services. Innovation is considered an environment or a culture that has almost a divine power which exists in the organization and which caused to drive value creation. (Robbins, Stepehen, \& Coulter, 1996) have identified three sets of variables that are responsible for stimulating innovation: organization's structure, organization's culture and HR practices.

\section{Rewards System}

Theory of reinforcement described that the rewards should be exploited to strengthen the appropriate behaviors only and reinforces for undesirable performance should be removed. Luthans (Luthans \& Youssef, 2007) states that an organization should have the most up-to-date technology, well-designed strategic plans, comprehensive job descriptions and inclusive training courses, but unfortunately, people are being rewarded based on performance-related behaviors of the employees, and there is a limited impact of technology, plans or rules. It is demonstrated that for reinforcing an organization's culture, the organization's reward system is considered a powerful tool. 


\section{Openness to Communication}

Chester Barnard states that functions of the executives were, firstly, to develop the thoughts of communication considered as a key shaping strength in an organization (Luthans \& Youssef, 2007). Good communication helps the employees to keep running internal processes consistently and also helps to create superior association with the people, both within and outside the organization. According to Luthans (Luthans \& Youssef, 2007 ) effective communication plays a very important role in industrial disagreements, miscommunication, gossips and organizational divergences.

\section{Customer Service Orientation}

Leveny Joel and Michelle (2000) state that employees observe the organization's procedures as believing them well and giving wisdom of society at workplace and got the customers' report regarding the quality of services. High service quality could result when the organizational culture communicates advanced customer service at the top.

\section{Hypothesis}

$H O=$ There is no association between organizational culture and employee performance.

$H 1=$ There is association between organizational culture and employee performance. 


\section{THEORETICAL FRAMEWORK}

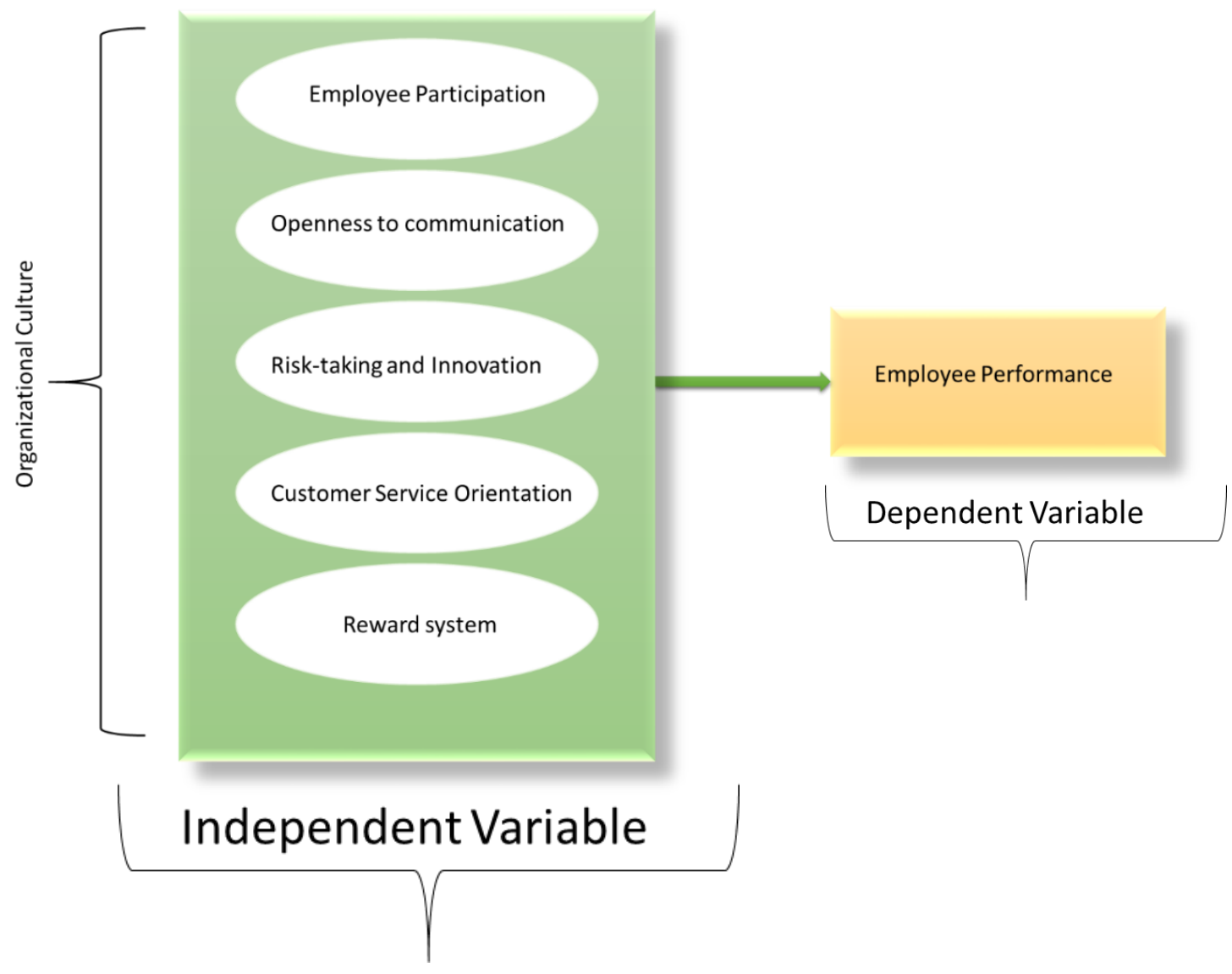

\section{RESEARCH METHODOLOGY}

\section{Research Design}

The research study is designed to evaluate the influence of organizational culture on employees' job performance for the software industry in Pakistan. For this purpose, culture is supposed as an independent variable, while performance is taken as a dependent variable. Certain parameters were considered to identify the relationship between culture and employees' performance within the selected software houses in Pakistan.

\section{Type of Research}

Type of this research study is quantitative. We are not using any qualitative data thus we can say it is mono type of research.

\section{Method of Research}

The study is aimed to test the already driven theory thus the deductive method of research has been used throughout the study. 


\section{Objective of Research}

The objective of the study is to investigate the impact of organizational culture on employee job performance at software houses in Pakistan.

\section{Technique / Way of Research}

Technique used in this research is questionnaires distributed randomly and the formal and informal interviews with the employees working at the software houses in Pakistan.

\section{Population and Sample}

\section{Population}

Population for this study was employees related to different software houses in distinctive areas of Pakistan, i.e., Eyesoftech, Tec2day, Soft vision, Net sole, lead concept, Next Bridge, Elixor and Trivor. For efficient coverage and lesser cost, stratified sampling was being utilized to select the contributing software houses.

\section{Sample}

The study sample included 150 employees working for different software house in Pakistan. Each employee was the sampling unit of the study. Random sampling technique has been used.

\section{Instrumentation}

Variables

\begin{tabular}{|l|l|}
\hline Independent Variable & Items \\
\hline Employee Participation & $\begin{array}{l}\text { How satisfied are you with the chances you have to take part in } \\
\text { decisions? }\end{array}$ \\
\hline Openness to Communication & $\begin{array}{l}\text { Are your suggestions followed? } \\
\text { How satisfied are you with the opportunities you have to express } \\
\text { grievances or complaints? } \\
\text { How satisfied are you with the way your grievances or complaints are } \\
\text { acted upon? }\end{array}$ \\
\hline Risk taking and Innovation & $\begin{array}{l}\text { My job is very challenging } \\
\text { Risk-taking is encouraged without fear of punishment for mistakes } \\
\text { Creativity and innovation are rewarded } \\
\text { Managers are receptive to change }\end{array}$ \\
\hline
\end{tabular}




\begin{tabular}{|l|l|}
\hline & $\begin{array}{l}\text { Employees are receptive to change } \\
\text { New practices and ways of doing business are encouraged }\end{array}$ \\
\hline Customer Service Innovation & $\begin{array}{l}\text { There are well-defined systems for linking customers' feedback and } \\
\text { complaints to employees who can act on the information. } \\
\text { I try to help customers achieve their goals. } \\
\text { I achieve my own goals by satisfying customers. } \\
\text { I take a problem-solving approach with my customers. } \\
\text { I am able to answer a customer's questions correctly. } \\
\text { I get customers to talk about their service needs with me. } \\
\text { I keep the best interests of the customer in mind. }\end{array}$ \\
\hline Reward system & $\begin{array}{l}\text { If you do your job especially well, how likely will you be given a } \\
\text { bonus or pay increase? } \\
\text { If you do your job especially well, how likely will you feel better } \\
\text { about yourself as a person? } \\
\text { If you do your job especially well, how likely will you be }\end{array}$ \\
\hline Adopted from: (Mirvis \& Lawler, 1984), (Paarlberg, 2007), (Grizzle, Zablah, Brown, Mowen, \& Lee, \\
2009), (Park, Lee, \& Kim, 2016)
\end{tabular}

\begin{tabular}{|c|c|}
\hline Dependent Variable & Items \\
\hline Employee job performance. & $\begin{array}{l}\text { How good is the quality of employees'work? } \\
\text { How productive are the employees. } \\
\text { How well employees do work with each other. } \\
\text { How well employees solve their problems independently. } \\
\text { How proactive employees are? } \\
\text { How well employees handle criticism. } \\
\text { How well employees adjust to changing priorities. } \\
\text { Do employees perform well without supervision as necessary? } \\
\text { How well do employees meet work deadlines? } \\
\text { How early do employees arrive at work? }\end{array}$ \\
\hline \multicolumn{2}{|c|}{$\begin{array}{l}\text { Adopted from (Odhiambo, LINDA FLORENCE and Ruto, Veronica J and Mutunga, Kamau and Kundu, } \\
\text { Joel M and Mugo, Judy Wamaitha and Otieno, John KR and Owuor, Isaac A and Mutinda, RN and } \\
\text { Tsindi, Tineyi T and Odinga, 2016) }\end{array}$} \\
\hline
\end{tabular}




\section{Validity and Reliability Test}

The main focus of this section is on the presentation and interpretation of data collected through the questionnaire distributed to employees of selected software houses. The collected data were studied by using SPSS (Statistical Package for Social Science) version 17. The results describe that organizational culture has a significant positive impact on employees' job performance. They demonstration that software houses in Pakistan have some common cultural characteristics.

\section{Ethical Considerations}

The following ways will address how participants were protected; firstly, there was a consent for voluntary participation of the employee, no employee was forced to fill the questionnaire or to give interviews. Secondly, it was mentioned that the secrecy and confidentiality will be preserved.

\section{Data Analysis Plan}

Correlation analysis and regression analysis were used to find the association between organizational culture and performance of employees.

\section{FINDINGS AND RESULTS}

\section{Descriptive Statistics}

To investigate the responses for independent and dependent variables, univariate analysis was used. Shows the value of minimum, maximum and standard deviation of independent and dependent variables. Mean value of OC is 2.947 , which indicates central tendency of variables. Standard deviation, minimum and maximum values indicate the dispersion from mean.

\section{Inferential Statistics}

Moreover, the bivariate analysis, regression analysis between job performance and organizational culture at the software houses in Pakistan, the value of adjusted $\mathrm{R}$ square is 0.716 , which represents that 71 per cent variation in employee performance is explained by organizational culture

Additionally, the result from the correlation matrix shows the value of Pearson's correlation between organizational culture and employees' performance is 0.415 . The value describes that there is a relationship between them, and significant value of 0.000 shows the significance of 
this relation; 0.415 is the positive value and indicates having a moderate effect because value is in between 0.3 and 0.7 .

\section{Hypothesis Summary}

Overall results supported the alternative hypothesis, which is $\mathrm{H} 1=$ There is association between organizational culture and employee performance; we found that organizational culture has a significant positive impact on the job performance of employees at selected software houses in Pakistan.

\section{DISCUSSION AND CONCLUSION}

In this study, the researcher tried to evaluate the overall impact of organizational culture on employees' job performance with regard to software houses in Pakistan. A questionnaire was developed, and distributed, and formal and informal interviews were also conducted for data collection.

The preliminary research question investigated the affiliation between five possible aspects of organizational culture, i.e., customer service, employee participation, reward system, innovation and risk-taking and communication system. The results show the positive relationship between organizational culture and employees' job performance at software houses in Pakistan. Correlation value was 0.415 and 0.000 was the level of significance, hence proof that there is a positive relation between organizational culture and employees' performance. Based on regression and correlation results, the alternative hypothesis shows the link between culture and employees' job performance within the organization.

Strong culture within the organization raises the employees' commitment toward achieving the goals of the organization within a common path. It is very helpful to increase the performance of the employees. Personal beliefs are different from the organizational values when an employee enters the organization. In a strong culture, employees are on the common path toward achieving organizational goals, which also provides an opportunity to the employees to grow in the organization (Deal \& Kennedy, 1982). Results showed that employees' commitment and participation are most important factors to increase organizational performance.

Female participation in the software industry is very low as compared to male participation, but after getting information, researchers concluded that culture of the software houses is not the only reason for low participation by females, and that technical skills and low rate of interest 
in software development are the main causes. Turnover rate of employees is also very high due to project-oriented nature of the software house industry.

\section{RECOMMENDATIONS}

Several gaps were existent when conducting this study. The data were collected only from those software houses which have national and international recognition. Low financial resources constrained the scope of this research. Considering a larger number of respondents for the study from various organizations will help confirm the validity and avoid generalizability of the findings and the results.

Future researchers can explore the relationship between employees' performance and their perceptions about culture across multiple organizations, which are evidently considered necessary. 


\section{REFERENCES}

Deal, T., \& Kennedy, A. (1982). Corporate cultures: The rites and rituals of organizational life. Reading/Mass: Addison-Wesley.

Gamble, P. R., \& Gibson, D. A. (1999). Executive Values and Decision Making: The Relationship of Culture and Information Flows. Journal of Management Studies. https://doi.org/10.1111/1467-6486.00134

Griffin, R; Moorhead, G. (2014). Organizational Behavior: Managing People and Organizations: Ricky W. Griffin, Gregory Moorhead. Cengage Learning.

Grizzle, J. W., Zablah, A. R., Brown, T. J., Mowen, J. C., \& Lee, J. M. (2009). Employee Customer Orientation in Context: How the Environment Moderates the Influence of Customer Orientation on Performance Outcomes. Journal of Applied Psychology. https://doi.org/10.1037/a0016404

Kopelman, R. E., Brief, A. P., \& Guzzo, R. A. (1990). The role of climate and culture in productivity. In Organisational climate and culture.

Leveny Joel and Michelle. (2000). Reflection for leaders corporate culture, organizational health, and human potential. Journal of Employee Assistance Professional Association Exchange.

Luthans, F., \& Youssef, C. M. (2007). Emerging positive organizational behavior. Journal of Management. https://doi.org/10.1177/0149206307300814

Mirvis, P. H., \& Lawler, E. E. (1984). Accounting for the quality of work life. Journal of Organizational Behavior. https://doi.org/10.1002/job.4030050304

Odhiambo, LINDA FLORENCE and Ruto, Veronica J and Mutunga, Kamau and Kundu, Joel M and Mugo, Judy Wamaitha and Otieno, John KR and Owuor, Isaac A and Mutinda, RN and Tsindi, Tineyi T and Odinga, T. O. and others. (2016). Influence of organizational culture on employee performance at NIC Bank Limited, Kenya. A Master Thesis Submitted to the School of Business, University of Nairobi.

Paarlberg, L. E. (2007). The impact of customer orientation on government employee performance. International Public Management Journal. https://doi.org/10.1080/10967490701323720 
Park, J., Lee, K. H., \& Kim, P. S. (2016). Participative Management and Perceived Organizational Performance: The Moderating Effects of Innovative Organizational Culture. Public Performance and Management Review. https://doi.org/10.1080/15309576.2015.1108773

Peters, T., \& Waterman, R. H. (1982). In Search of Excellence: Simultaneous Loose-Tight Properties. In Search of Excellence: Lessons from America's Best-Run Companies.

Pillania, R. K., Victoria Garibaldi Hilal, A., Wetzel, U., \& Ferreira, V. (2009). Organizational culture and performance: a Brazilian case. Management Research News. https://doi.org/10.1108/01409170910927578

Robbins, Stepehen P and Coulter, M. (1996). Management, USA: Person Education. Inc.

Robbins, S. P. (1996). Organizational Behavior: Concepts, Controversies and Applications. In Development.

Schein, E. H. (1992). Organizational culture and leadership Jossey-Bass. San Francisco, CA. https://doi.org/10.2307/977097

Shahzad, F. (2012). Impact of Organizational Culture on Organizational Performance : An Overview. Interdisciplinary Journal of Contemporary Research in Business.

Sofijanova, E Zabijakin-Chatleska, V. (2013). Employee Involvement and Organizational Performance: Evidence from the Manufacturing Sector in Republic of. Trakia Journal of Sciences.

Uma, M. H. (2015). Employee Participation: A Tool of Motivation and High Productivity. Pacific Business Review International.

Zairi, M. (1999). Process innovation management. Butterworth Heinemann, London. 